\title{
In Vitro Molecular Biology Studies of Spirooxindole Heterocyclic Hybrids
}

\author{
Dhaifallah M. Al-thamili, Abdulrahman I. Almansour, Natarajan Arumugam®, \\ Faruq Mohammad $(D)$ and Raju Suresh Kumar *(D) \\ Department of Chemistry, College of Science, King Saud University, P.O. Box 2455, Riyadh 11451, Saudi Arabia; \\ daife54321@hotmail.com (D.M.A.-t.); almansor@ksu.edu.sa (A.I.A.); anatarajan@ksu.edu.sa (N.A.); \\ farooqm1983@gmail.com (F.M.) \\ * Correspondence: sraju@ksu.edu.sa
}

Received: 5 October 2020; Accepted: 16 November 2020; Published: 17 November 2020

check for updates

\begin{abstract}
In the present report, we provide the results of the molecular biology studies of spiroheterocyclic hybrids, where the derivatives are found to possess potential anticancer activity towards cancer cells. A series of spiroxindole-pyrrolidine heterocyclic hybrids were evaluated for cell viability and proliferation against HepG2 cancer cells at concentrations in the range of $12.5-200 \mu \mathrm{g} / \mathrm{mL}$ over two different time periods of 24 and $48 \mathrm{~h}$. In addition, the highly active compounds were also verified for their behavior towards noncancer cells (L929 cells), and it was found that the tested derivatives were not aggressive due to the observation of only limited cell loss, as compared to the cancer cells. Further analysis of the observed toxicity mechanism showed the apoptotic pathway was mediated by oxidative stress, with the involvement of caspases.
\end{abstract}

Keywords: functionalized spiroheterocycles; anticancer activity; controlled cell death; apoptosis; ROS generation; caspase-3 activity

\section{Introduction}

Cancer, an uncontrolled growth of abnormal cells, is the second foremost origin of death worldwide after heart disease [1-3]. Cancer is the cause of nearly 14 million demises every year and this number is predicted to double by the year 2030. Cancerous diseases are mostly complicated in humans and can originate in various organs like breast, colon, lung, stomach, and liver, to mention a few [4]. In order to treat such cancerous diseases, various treatment modalities are available, but each method has its own limitations. Among many different treatment modalities, cancer chemotherapy has proven to be easy and proficient for the eradication of aggressive cancer cells without causing trouble to normal cells at a higher level [5]. For the successful implementation of this chemotherapeutic treatment, the selection and recognition of highly active chemical moieties are of the highest significance because of the determined ability of the tumor cell's immune response towards traditional chemotherapeutic agents. Since multidrug resistance development is one of the major challenges associated with the current chemotherapeutics, continuous research is highly demanded in the oncology sector for the identification and testing of novel chemo-moieties that can offer lesser toxicities and uplifted efficiencies [6,7].

Apoptosis, also called programmed cell death, is a highly preferred mechanism for the control of tumor cells, which generally occurs through oxidative stress and DNA damage when the cells lose their capacity to repair the damage caused by the therapeutic/anticancer drugs. In addition, the repair mechanism associated with the apoptosis process helps to control the aggressive growth and proliferation of unwanted cells [8]. Hence, any defects involved in the apoptotic signaling process may lead to the propagation of various diseases in humans, which mainly includes cancer. The cancer cells that develop in such a way contribute to the growth of unwanted masses, called "tumors", 
by surviving over their intended life spans, subverting them from the need for exogenous survival factors and protecting them from oxidative stress and hypoxia. Thus, the developed tumors maintain the genetically altered cells, which promote angiogenesis, deregulate the normal cell proliferation process, interfere with cell differentiation, and increase the possibilities of invasiveness during the progression stage. Therefore, restoring the natural capacity of diseased cells to easily participate in the normal apoptotic process can be a reliable strategy in potential cancer treatments [9].

Spiropyrrolidine-oxindole molecular scaffolds hold interesting structural features and robust bioactivity profiles, including antibacterial [10], antiviral [11], anticancer [12-14], and local anesthetic activities [15], and have ensued as promising synthetic targets. The activity of such central ring systems for the exploration and exploitation of pharmacophore space via diversity-oriented synthesis (DOS) has led to the discovery of new drug candidates [16,17]. For instance, natural spirooxindoles viz. horsfiline [18], and elacomine [19] display important biological activities [20,21]. Notably, even non-natural spirooxindoles, namely, MI-773 and MI-888 (Figure 1), maintain the capacity to control the cell-cycle and protein-protein interactions associated with the nonpeptidic inhibitors of p53-MDM2, which, in general, is considered as dangerous for the $\mathrm{p} 53$ protein's activity of tumor-suppression. Further, inhibiting the MDM2-p53 protein interactions can have potential therapeutic implications in cancer treatment [22].<smiles>COc1ccc2c(c1)[C@]1(CCN(C)C1)C(=O)N2</smiles>

Horsfiline<smiles>CC(C)(C)C[C@H]1N[C@H](C(=O)NC2CCC(O)CC2)[C@H](c2cccc(Cl)c2F)[C@@]12C(=O)Nc1cc(Cl)ccc12</smiles>

Ml-773<smiles>CC(C)CC1NCC[C@]12C(=O)Nc1cc(O)ccc12</smiles>

Elacomine<smiles>CC1(O)CC(NC(=O)[C@H]2NC(C(C)(C)C)[C@]3(C(=O)Nc4cc(Cl)ccc43)[C@H]2c2cccc(Cl)c2F)C1</smiles>

MI-888<smiles>O=C1C(=CBr)CNCC12NC(=O)C1(C(=O)Nc3ccccc31)[C@H](c1ccccc1)C2Br</smiles>

A

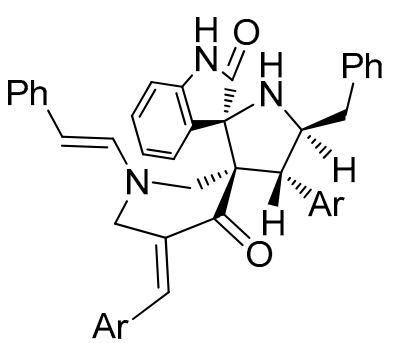

B

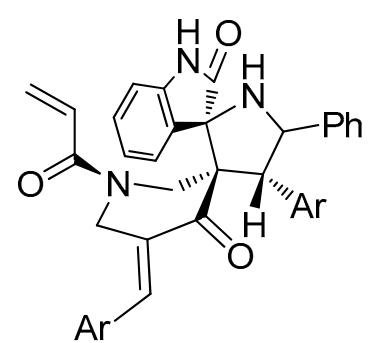

C

Figure 1. Representative natural and unnatural spirooxindole-pyrrolidine heterocyclic hybrids. (A) The spirooxindole-pyrrolidine heterocyclic hybrids, (B) The N-styryl-substituted spirooxindole-pyrrolidine heterocyclic hybrids, (C) The $\mathrm{N}$-acrolyl derivatives. 
In this context, we have been engaged in the exploration of the biological potential of spiropyrrolidine-oxindole heterocyclic hybrids. For instance, the spirooxindole-pyrrolidine heterocyclic hybrids (A) with unsubstituted piperidone moiety have displayed promising anticancer activity in leukemia lymphoblastic (CCRF-CEM), human breast carcinoma (MDA-MB-231), and ovarian carcinoma (SK-OV-3) cells [23]. Additionally, the N-styryl-substituted spirooxindole-pyrrolidine heterocyclic hybrids (B) have displayed potent anticancer activities as well [24,25]. Moreover, the $\mathrm{N}$-acrolyl derivatives (C) displayed promising cholinesterase inhibitory activities [26]. Furthermore, compounds embedded with $N$-pyridyl structural subunits have been shown to exhibit good-to-excellent anticancer activities against HepG2 cells [27]. It is pertinent to note that the inherent ability of spiroheterocyclic hybrids to project functionality in all three dimensions facilitates easy interactions of ligands with the three-dimensional binding site of spiroheterocyclic hybrids than with planar systems $[28,29]$. Prompted by this characteristic feature and the abovementioned biological precedents of the spiroheterocyclic hybrids, herein, we present the behavior of spiropyrrolidine-oxindole heterocyclic hybrids derived from $N$-pyridyl-4-piperidone- $\alpha, \beta$-unsaturated ketones towards cancer and noncancer cells. We presume the molecular hybridization of spirooxindole, pyrrolidine, piperidone, and $N$-pyridy units embedded with an $\alpha, \beta$-unsaturated ketone moiety into new single hybrid architectures, with preselected activities of the original individual subunits that would enhance the biological profiles of new constructs. In one of our recent studies, we investigated the biological potential of $N$-pyridyl 4-piperidones embedded with an $\alpha, \beta$-unsaturated ketone moiety [30]. As a continuation, we present our findings of $N$-pyridyl-substituted spirooxindole-pyrrolidine heterocyclic hybrids constructed through the aforementioned $N$-pyridyl 4-piperidone $\alpha, \beta$-unsaturated ketones and their molecular biology activities towards cancer and noncancer cells.

\section{Materials and Methods}

The selection of cell lines and all the assay protocols for testing the anticancer activity and intracellular mechanisms of spirooxindole-pyrrolidine heterocyclic hybrids were in accordance with our recently published article [30]. The derivatives $\mathbf{1}(\mathbf{a}-\mathbf{h})$ with a range of concentrations $(12.5-200 \mu \mathrm{g} / \mathrm{mL})$ were first tested against HepG2 cancer cells over an incubation period of 24-48 h. From those studies, the two most active compounds (1) and $\mathbf{1 f}$ ) were carried over to test for cell viability and proliferation against the L929 noncancer cell line. Furthermore, the intracellular mechanistic pathways of treatment with highly active compound $\mathbf{1} \mathbf{b}$ were studied against the cancer cell line by means of apoptosis, oxidative stress, and caspase activity assays. For the analysis, melphalan (Mel; $15 \mu \mathrm{g} / \mathrm{mL})$ was used as the positive control, and cells without any treatment were used as the negative control. Additionally, based on statistical analysis, ${ }^{*}$ corresponds to significant values $(p<0.05)$ and ${ }^{* *}$ to highly significant $(p<0.01)$ values against the control measurements. The detailed procedure for the maintenance of cell cultures and assay protocols is provided in the supporting information file.

\section{Results and Discussion}

The required $N$-pyridyl-spirooxindole-pyrrolidine heterocyclic hybrids $\mathbf{1}(\mathbf{a}-\mathbf{h})$ were synthesized in accordance with our recent study [31]. The molecular structure of these heterocyclic hybrids 1(a-h) is shown in Scheme 1. Initially, these heterocyclic hybrids $\mathbf{1}(\mathbf{a}-\mathbf{h})$ were tested for their anticancer potential against the HepG2cancer cell line. The in-vitro cell viability studies, following the incubation of HepG2 cancer cells with that of the test compounds $\mathbf{1}(\mathbf{a}-\mathbf{h})$ at concentrations in the range of $12.5-200 \mu \mathrm{g} / \mathrm{mL}$ over 24 and $48 \mathrm{~h}$, are shown in Figures 2 and 3, respectively. 


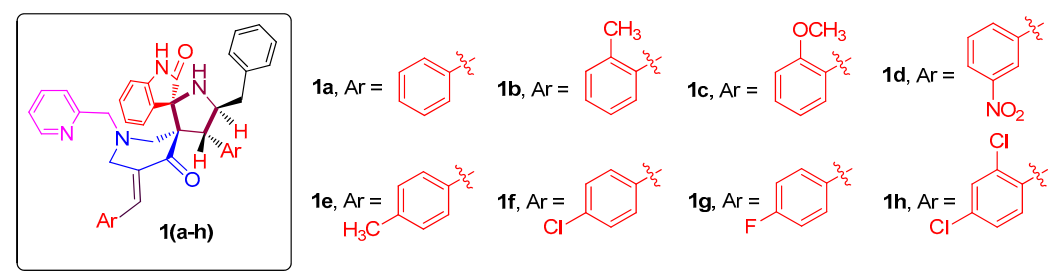

Scheme 1. Schematic representation of spirooxindole-pyrrolidine heterocyclic hybrids of the present study.

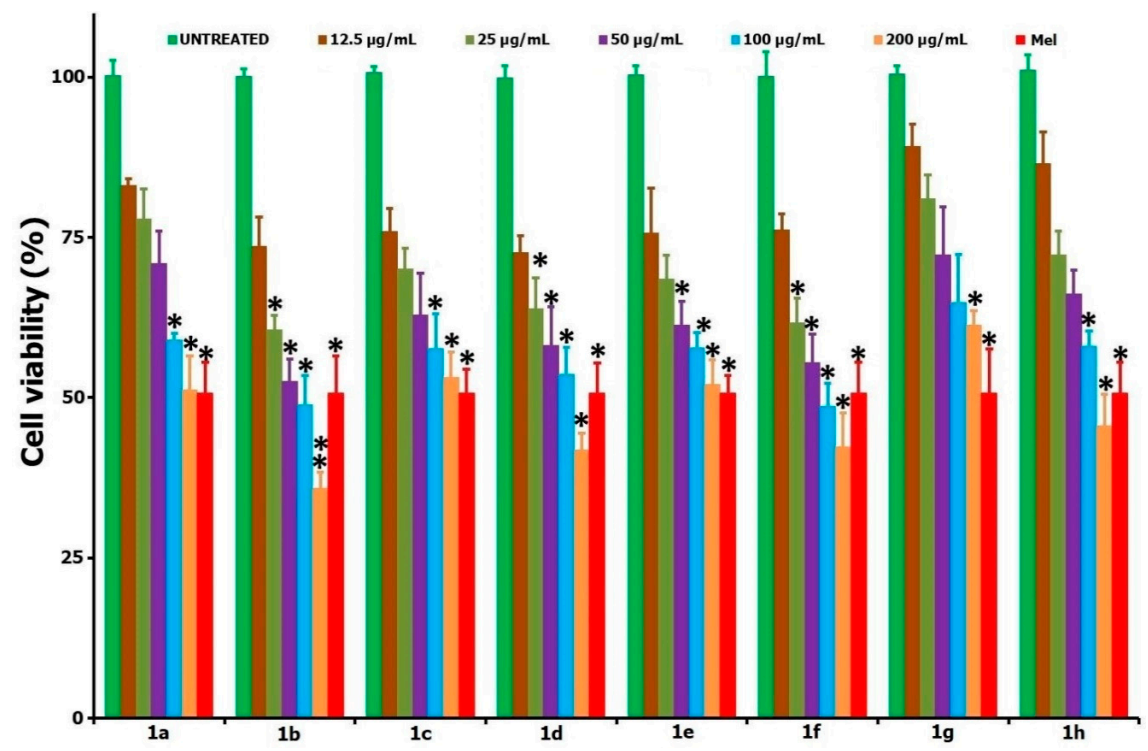

Figure 2. The percentage viability of HepG2 cancer cells when treated with the synthesized derivatives $\mathbf{1}(\mathbf{a}-\mathbf{h})$ in the concentration range of $12.5-200 \mu \mathrm{g} / \mathrm{mL}$ and compared with that of positive (melphalan (Mel); $15 \mu \mathrm{g} / \mathrm{mL}$ ) and negative controls (no treatment) over a $24 \mathrm{~h}$ period. ${ }^{*}$ and ${ }^{* *}$ correspond to significant $(p<0.05)$ and highly significant $(p<0.01)$ values against the untreated control.

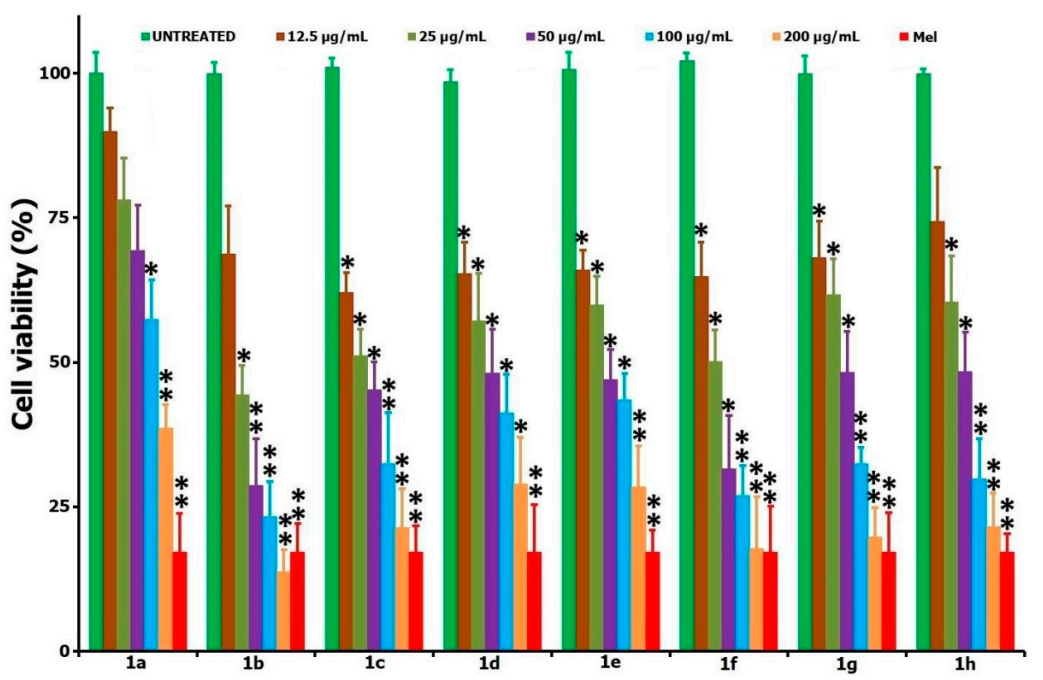

Figure 3. The percentage viability of HepG2 cancer cells, followed by the treatment of synthesized derivatives $\mathbf{1}(\mathbf{a}-\mathbf{h})$ in the concentration range of $12.5-200 \mu \mathrm{g} / \mathrm{mL}$ and compared against the positive control (Mel; $15 \mu \mathrm{g} / \mathrm{mL}$ ) and negative control (no treatment) over a $48 \mathrm{~h}$ period. * and ${ }^{* *}$ correspond to significant $(p<0.05)$ and highly significant $(p<0.01)$ values against the untreated control.

From the comparative analysis of the obtained results (Figure 2), all the tested compounds exhibited some level of activity against the cancer cells as we observed a significant number of cell losses starting from $50 \mu \mathrm{g} / \mathrm{mL}$ concentration ( $48 \%$ cell loss) over a $24-\mathrm{h}$ period (as compared against 
positive control of Mel and negative control of no treatment). Additionally, with an increase of the incubation period to $48 \mathrm{~h}$ (Figure 3), this activity increased (72\% cell loss at the same concentration of $50 \mu \mathrm{g} / \mathrm{mL}$ ) due to increased interaction of the testing compounds with the cells. The $\mathrm{IC}_{50}$ values, following the incubation of synthesized compounds $\mathbf{1}(\mathbf{a}-\mathbf{h})$ with that of HepG2 cancer cells for 24 and $48 \mathrm{~h}$, are tabulated in Table 1 . From the comparison of $\mathrm{IC}_{50}$ values, the least activity was observed for compound $1 \mathrm{~g}$ at $24 \mathrm{~h}$ and compound $1 \mathrm{a}$ at $48 \mathrm{~h}$ incubation periods. However, the highest activity was noted for compound $\mathbf{1 b}$, followed by compound $\mathbf{1 f}$, at both the incubation periods of 24 and $48 \mathrm{~h}$. Based on the 3-(4,5-dimethylthiazol-2-yl)-2,5-diphenyl tetrazolium bromide (MTT) assay results, the anticancer activity and the associated $\mathrm{IC}_{50}$ values order during the $24 \mathrm{~h}$ incubation period is $\mathbf{1 b}>\mathbf{1 f}>\mathbf{1 d}>\mathbf{1 h}>\mathbf{1 a}>\mathbf{1 e}>\mathbf{1 c}>\mathbf{1 g}$, while for the $48 \mathrm{~h}$ period, it is $\mathbf{1 b}>\mathbf{1 f}>\mathbf{1 c}>\mathbf{1 g}>\mathbf{1 h}>\mathbf{1 d}>\mathbf{1 e}>\mathbf{1 a}$.

Table 1. Comparison of the $\mathrm{IC}_{50}$ values of the tested compounds $\mathbf{1}(\mathbf{a}-\mathbf{h})$ against HepG2 cells over 24 and $48 \mathrm{~h}$ incubation periods.

\begin{tabular}{|c|c|c|c|c|}
\hline \multirow{2}{*}{ Entry } & \multirow{2}{*}{ Compound } & \multirow{2}{*}{$\begin{array}{c}\begin{array}{c}\mathrm{IC}_{50} \text { Values in } \\
\mu \mathrm{g} / \mathrm{mL}(\mu \mathrm{M}) ; 24 \mathrm{~h}\end{array} \\
\text { HepG2 Cells }\end{array}$} & \multicolumn{2}{|c|}{$\mathrm{IC}_{50}$ Values in $\mu \mathrm{g} / \mathrm{mL}(\mu \mathrm{M}) ; 48 \mathrm{~h}$} \\
\hline & & & HepG2 Cells & L929 Cells \\
\hline 1 & & $\begin{array}{c}237.59 \pm 12.5 \\
(385.23 \pm 20.27)\end{array}$ & $\begin{array}{c}126.81 \pm 10.4 \\
(205.61 \pm 16.86)\end{array}$ & - \\
\hline 2 & & $\begin{array}{c}72.24 \pm 8.7 \\
(112.03 \pm 13.49)\end{array}$ & $\begin{array}{c}23.81 \pm 2.3 \\
(36.92 \pm 3.57)\end{array}$ & $\begin{array}{c}301.72 \pm 12.51 \\
(467.93 \pm 19.40)\end{array}$ \\
\hline 3 & & $\begin{array}{c}265.24 \pm 9.4 \\
(391.90 \pm 13.89)\end{array}$ & $\begin{array}{c}29.83 \pm 2.1 \\
(44.07 \pm 3.10)\end{array}$ & - \\
\hline 4 & & $\begin{array}{c}107.74 \pm 7.5 \\
(152.44 \pm 10.62)\end{array}$ & $\begin{array}{c}44.1 \pm 2.6 \\
(62.40 \pm 3.68)\end{array}$ & - \\
\hline
\end{tabular}


Table 1. Cont.

\begin{tabular}{|c|c|c|c|c|}
\hline \multirow{2}{*}{ Entry } & \multirow{2}{*}{ Compound } & \multirow{2}{*}{$\begin{array}{c}\begin{array}{c}\mathrm{IC}_{50} \text { Values in } \\
\mu \mathrm{g} / \mathrm{mL}(\mu \mathrm{M}) ; 24 \mathrm{~h}\end{array} \\
\text { HepG2 Cells }\end{array}$} & \multicolumn{2}{|c|}{$\mathrm{IC}_{50}$ Values in $\mu \mathrm{g} / \mathrm{mL}(\mu \mathrm{M}) ; 48 \mathrm{~h}$} \\
\hline & & & HepG2 Cells & L929 Cells \\
\hline 5 & & $\begin{array}{c}237.64 \pm 8.9 \\
(368.55 \pm 13.80)\end{array}$ & $\begin{array}{c}45.86 \pm 2.8 \\
(71.12 \pm 4.34)\end{array}$ & - \\
\hline 6 & & $\begin{array}{c}90.01 \pm 5.6 \\
(131.28 \pm 8.17)\end{array}$ & $\begin{array}{c}25.01 \pm 3.2 \\
(36.48 \pm 4.67)\end{array}$ & $\begin{array}{c}257.16 \pm 9.6 \\
(375.06 \pm 14.00)\end{array}$ \\
\hline 7 & & $\begin{array}{c}509.28 \pm 14.3 \\
(780.23 \pm 21.91)\end{array}$ & $\begin{array}{c}40.51 \pm 3.6 \\
(62.06 \pm 5.52)\end{array}$ & - \\
\hline 8 & & $\begin{array}{c}157.27 \pm 11.3 \\
(208.43 \pm 14.98)\end{array}$ & $\begin{array}{c}43.17 \pm 4.5 \\
(57.21 \pm 5.96)\end{array}$ & - \\
\hline 9 & & - & - & - \\
\hline & Mel & & & \\
\hline
\end{tabular}

The MTT studies (HepG2 cancer cells) for the synthesized derivatives indicated that compounds $\mathbf{1 b}$ and $\mathbf{1 f}$ are highly active at the highest incubation period of $48 \mathrm{~h}$, and hence, we selected these two compounds and assay conditions for the following analysis. Therefore, to test the behavior of highly active compounds $\mathbf{1 b}$ and $\mathbf{1 f}$ on healthy normal cells, the noncancer L929 cells were studied by incubating them at $12.5-200 \mu \mathrm{g} / \mathrm{mL}$ concentration over a $48-\mathrm{h}$ period (Figure 4 ). From the comparative analysis of the results with that of positive and negative controls, both compounds $\mathbf{1 b}$ and $\mathbf{1 f}$ were not 
found to induce significant cell viability losses, as we observed only $18 \%$ loss for compound $\mathbf{1 b}$ and $22 \%$ loss for compound 1f at $50 \mu \mathrm{g} / \mathrm{mL}$ concentration. The cells at the highest tested concentration of $200 \mu \mathrm{g} / \mathrm{mL}$ provided approximately $40 \%$ loss, indicating that the compounds were behaving in a safe manner towards the noncancer cells while offering anticancer activity against the cancer cells. In addition, the information provided in Table 1 indicates that compound $\mathbf{1 b}$ has the $\mathrm{IC}_{50}$ value of $301 \mu \mathrm{g} / \mathrm{mL}$, while compound $\mathbf{1 f}$ has the IC50 value of $257 \mu \mathrm{g} / \mathrm{mL}$; these values are quite high compared to the cancer cell $\mathrm{IC}_{50}$ values. Thus, taking into consideration such variation in the activity of our synthesized compounds against cancer and noncancer cells, it can be inferred that compounds $\mathbf{1 b}$ and If potentially serve as safe therapeutic agents.

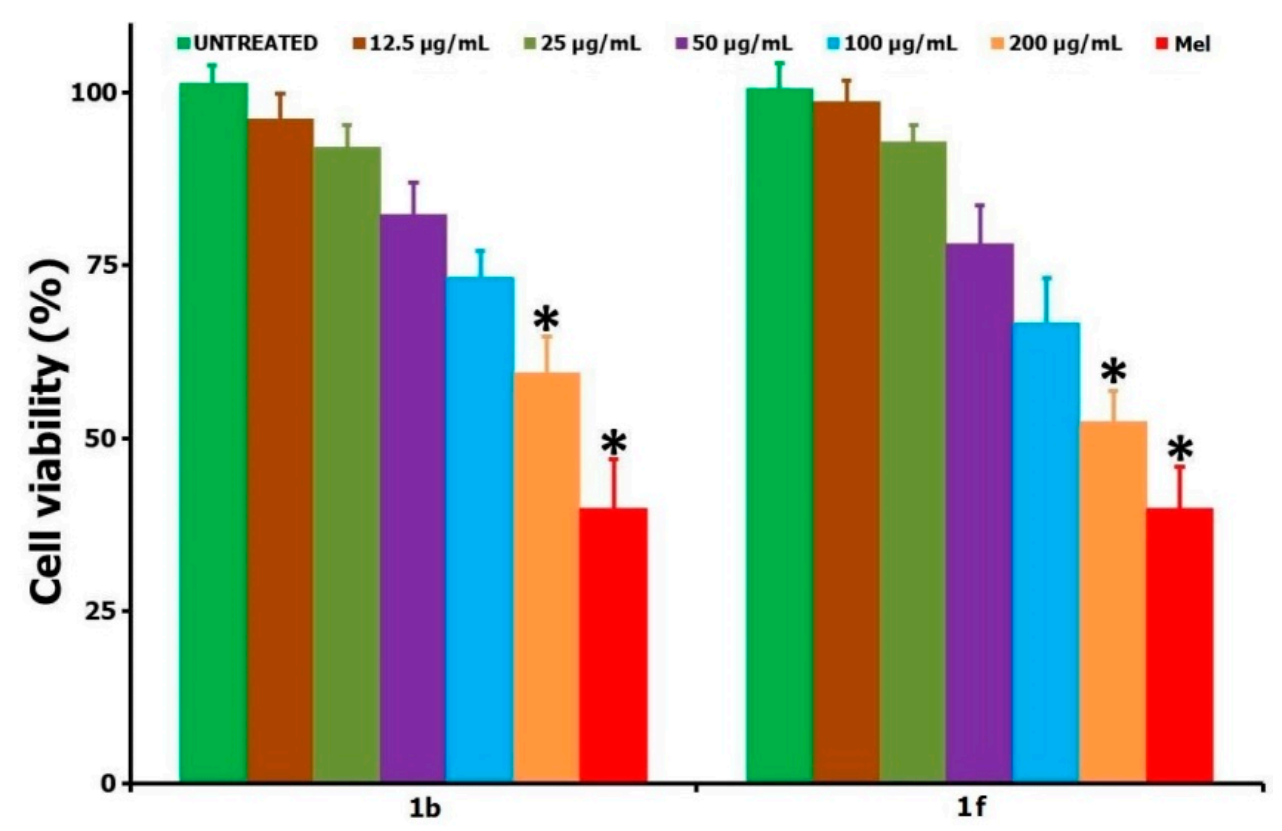

Figure 4. The percentage viability of L929 noncancer cells, followed by the treatment of compounds $\mathbf{1 b}$ and $\mathbf{1 f}$ at concentrations in the range of $12.5-200 \mu \mathrm{g} / \mathrm{mL}$ ( $48 \mathrm{~h}$ period). Positive control of Mel $(15 \mu \mathrm{g} / \mathrm{mL})$ and negative control of cells without any treatment were applied. ${ }^{*}$ corresponds to significant $(p<0.05)$ values against the untreated control.

Figure 5 shows the comparison of the flow cytometry of the apoptotic assay results for the highly active compound $\mathbf{1 b}$ at its $\mathrm{IC}_{50}$ concentration $(24 \mu \mathrm{g} / \mathrm{mL} ; 37 \mu \mathrm{M})$ with that of positive control (Mel; $15 \mu \mathrm{g} / \mathrm{mL}$ ) and negative control (cells without any treatment). From Figure 5, A-1, B-1, and C-1 correspond to the total population of cells used for the fluorescence analysis of the negative control, the positive control (Mel), and compound 1b, respectively. Similarly, A-2 (untreated control), B-2 (Mel), and C-2 (compound 1b) correspond to the combined fluorescence of PI and Annexin-V-FITC, while A-3 (untreated control), B-3 (Mel), and C-3 (compound 1b) correspond to the Annexin-V-FITC fluorescence intensity. From the analysis, it was found that the compound-1b-treated cells (Figure 5, C-2) exhibited about $48 \%$ live, $6 \%$ early-apoptotic, 37\% late-apoptotic, and 7\% necrotic cells. However, the positive control (Mel)-treated cells (Figure 5, B-2) had 2\% early-apoptotic, 46\% late-apoptotic, and $34 \%$ necrotic cells, while the negative control cells had $97 \%$ live cells. The comparison of our compound $\mathbf{1 b}$ result (Figure 5, C-2) with that of positive (Figure 5, B-2) and negative controls (Figure 5, A-2) can primarily indicate the occurrence of a late-apoptotic mechanism. Furthermore, the compound-1b-treated cells (Figure 5, C-3) indicated the M1 and M2 values of 37\% (normal cells) and 63\% (apoptotic cells), similar to the positive control (Figure 5, B-3; 35\% normal and 65\% apoptotic), and thereby confirm an exclusive apoptotic pathway in the cancer cells. 

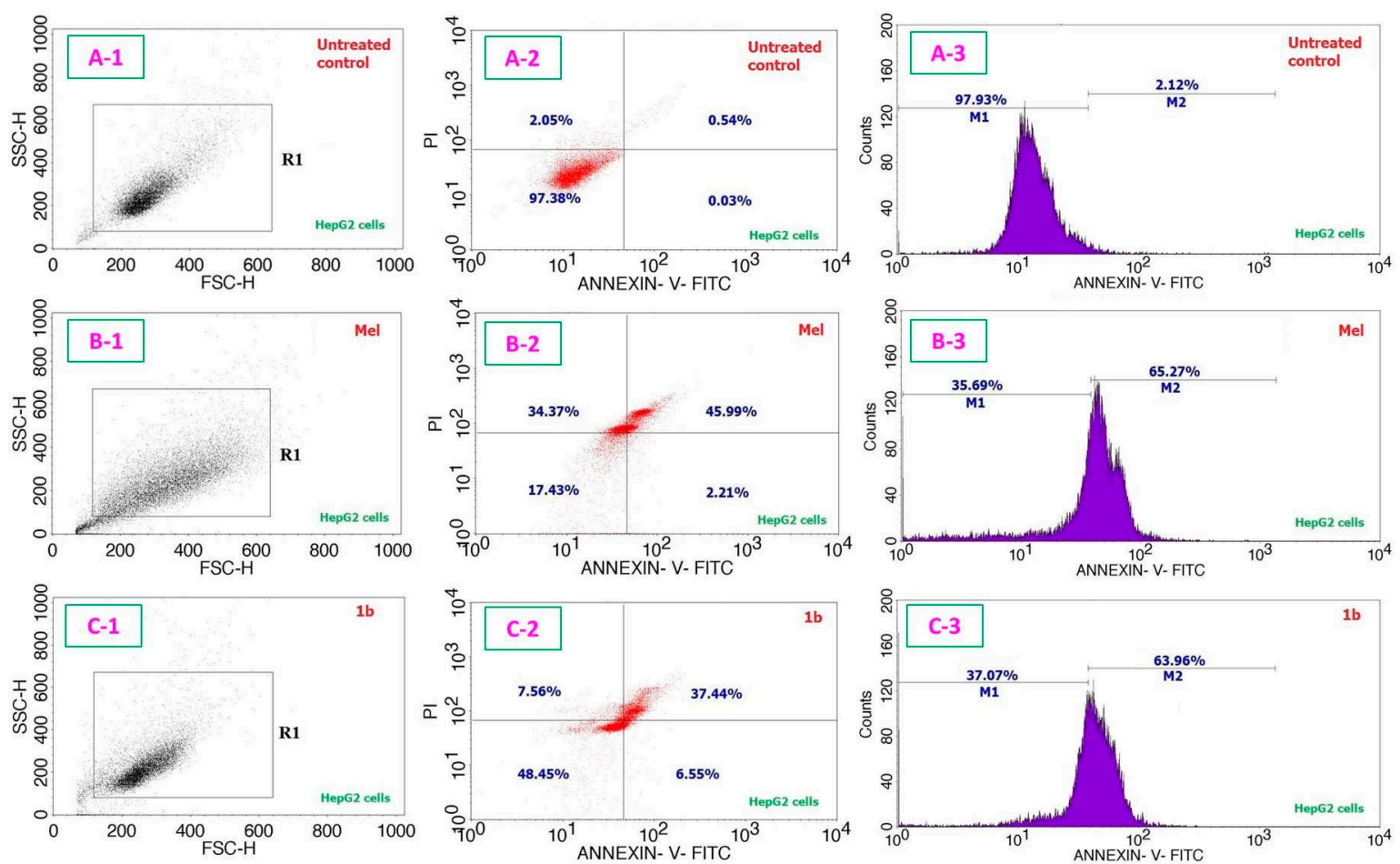

Figure 5. Comparison of apoptosis assay results for HepG2 cancer cells at $48 \mathrm{~h}$ incubation period. From the figure, A, B, and C correspond to the negative control, the positive control (Mel; $15 \mu \mathrm{g} / \mathrm{mL}$ ), and compound $\mathbf{1 b}$, respectively, while 1, 2, and 3 stand for the population of cells selected for the analysis (FSC-H: forward scatter histogram; SSC-H: side scatter histogram), combined fluorescence from PI and Annexin-V-FITC, and pure Annexin-V-FITC fluorescence, respectively.

Figure 6 shows the comparison of ROS assay results provided by flow cytometry for the highly active compound $\mathbf{1} \mathbf{b}$ at its $\mathrm{IC}_{50}$ concentration $(24 \mu \mathrm{g} / \mathrm{mL}$ ) with that of positive control (Mel; $15 \mu \mathrm{g} / \mathrm{mL}$ ) and negative control (cells without any treatment). From the figure, the population of cells tested for the flow cytometric analysis of the ROS assay is represented in Figure 6 of A-1 (negative control), B-1 (positive control), and C-1 (compound $1 \mathrm{~b}$ ), while the corresponding sample's $\mathrm{H}_{2}$ DCFDA fluorescence population are in A-2, B-2, and C-2, respectively. The $\mathrm{H}_{2}$ DCFDA fluorescence intensities from the negative control, the positive control, and compound $\mathbf{1} \mathbf{b}$ are compared in Figure 6 (A-3, B-3, and C-3, respectively). From the comparison of fluorescence intensities for compound-1b-treated cells (Figure 6, C-3), about $10 \%$ of cells (M1) were normal and $89 \%$ (M2) were experiencing ROS-mediated oxidative stress. This is quite high when compared to the M1 and M2 values indicated by positive-control-treated cells (Figure 6, B-3), i.e., 86\% normal and 13\% ROS-producing cells (respectively), and, thereby, confirms the oxidative ability of our synthesized compound $\mathbf{1 b}$.

Figure 7 shows the comparison of the caspase- 3 activity of compound $\mathbf{1 b}(24 \mu \mathrm{g} / \mathrm{mL}$ concentration) with that of positive control (Mel; $15 \mu \mathrm{g} / \mathrm{mL}$ ) and negative control (cells without any treatment). From Figure 7d, the compound-1b-treated cells exhibited higher relative fluorescence intensity than of positive-control-treated cells, and the same can also be visualized from the cells in Figure $7 \mathrm{~b}, \mathrm{c}$. Green fluorescence is observed in the cells that are activated through the release of caspase- 3 proteins, and, at the same time, the cells are alive and undergoing the apoptotic pathway because of the effect of compound $\mathbf{1 b}$. The observation of high fluorescence levels for the compound-1b-treated cancer cells confirms the active role played by the caspases (in support of caspase-3 activity). However, no significant fluorescence is observed in the untreated controls (Figure 7a) because of the absence of caspase activity, while slight fluorescence in Mel (Figure $7 \mathrm{~b}$ ) and significant fluorescence in compound-1b-treated cells (Figure 7c) confirm the caspase-3 activity, along with the apoptosis mechanism in live cells. 

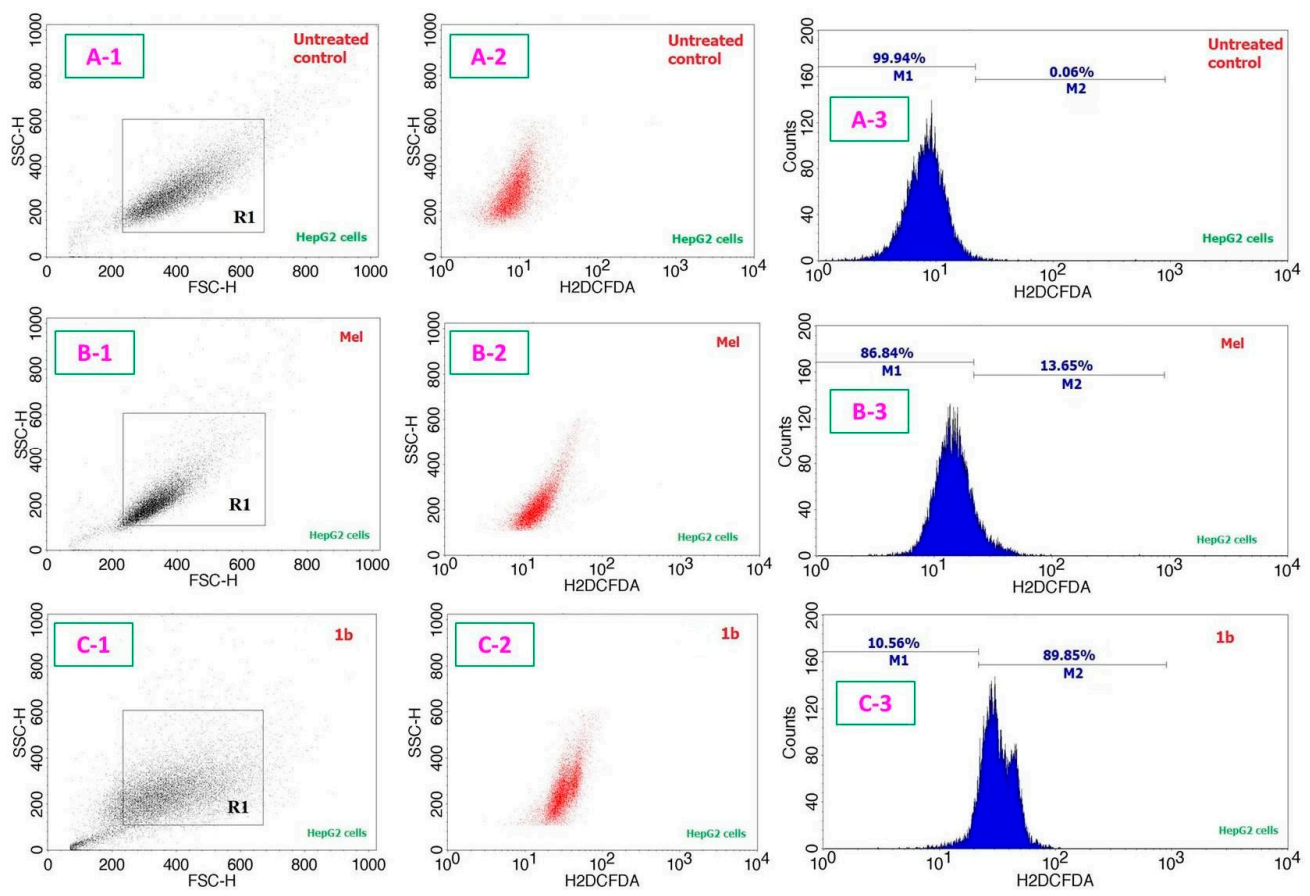

Figure 6. Comparison of flow cytometric analysis results for ROS generation in HepG2 cancer cells at $48 \mathrm{~h}$ incubation. From the figure, A, B, and C correspond to the negative control (without any treatment), the positive control (Mel; $15 \mu \mathrm{g} / \mathrm{mL}$ ), and compound $\mathbf{1 b}$ (at $\mathrm{IC}_{50}$ ), respectively, while 1, 2, and 3 stand for the cell population tested, number of cells exhibiting $\mathrm{H}_{2}$ DCFDA fluorescence, and \% of fluorescent intensity, respectively.
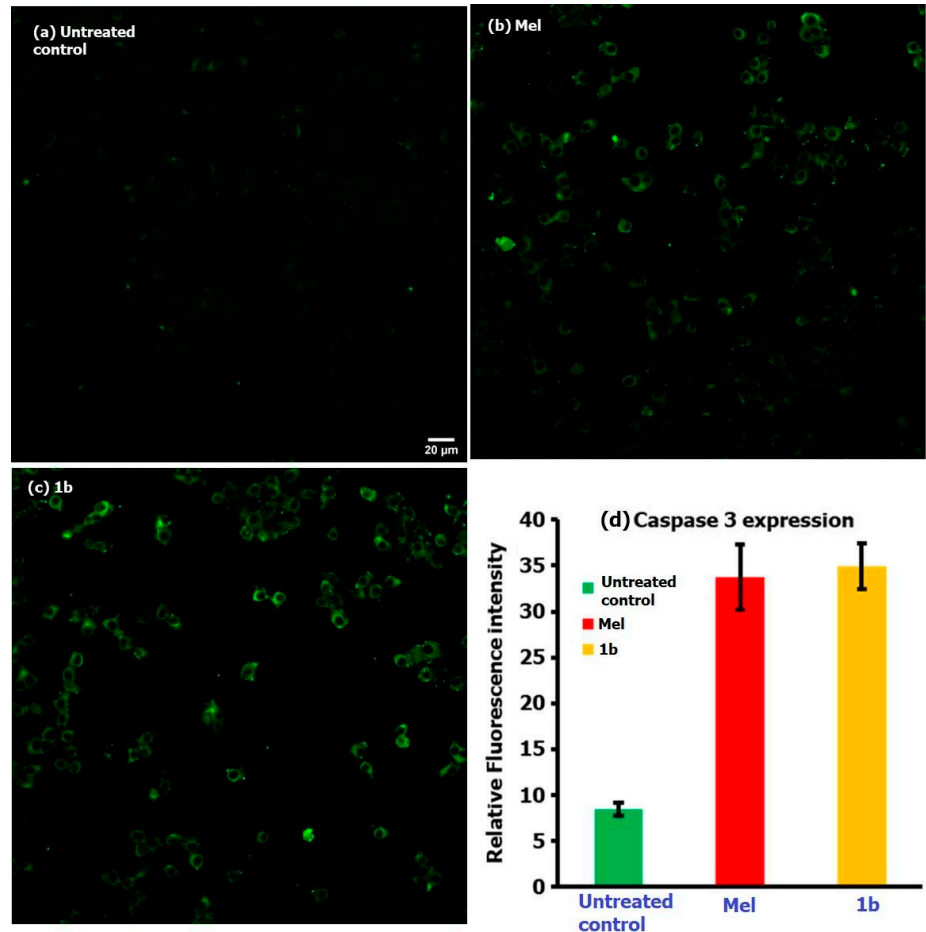

Figure 7. Caspase 3 activity comparison of HepG2 cancer cells, followed by the treatment of $\mathrm{IC}_{50}$ concentration of compound $\mathbf{1 b}$ (c) with that of positive control of Mel $(15 \mu \mathrm{g} / \mathrm{mL})(\mathbf{b})$ and negative control (a) over a $48 \mathrm{~h}$ period. Relative fluorescence intensity of all the samples is compared in (d). 
In the present study, the anticancer activity of spirooxindole-pyrrolidine heterocyclic hybrids has been investigated against cancer cells, where the results have proven that all the derivatives exhibit some level of activity. This activity seems to increase with that of concentration and incubation period, and the highly active compound was found to be $1 \mathbf{b}$, with the lowest IC $_{50}$ value of $\sim 24 \mu \mathrm{g} / \mathrm{mL}$ over a treatment time of $48 \mathrm{~h}$. Further testing of the intracellular pathways followed by compound $\mathbf{1 b}$ treatment proved that the cancer cells are experiencing the apoptotic mechanism, with the release of oxidative stress mediated by ROS and the involvement of caspases. Comparing the present study results with that of our recently published work [31], it primarily indicates that the spirooxindole-pyrrolidine heterocycles are a little less active than the $N$-pyridinylmethyl-engrafted bisarylmethylidenepyridinones. The lower activity is reflected in the form of $\mathrm{IC}_{50}$ values, i.e., we observed lower activity at about $12 \mu \mathrm{g} / \mathrm{mL}(24 \mathrm{~h})$ for the $\mathrm{N}$-pyridinylmethyl-engrafted bisarylmethylidenepyridinones and at $24 \mu \mathrm{g} / \mathrm{mL}$ ( $48 \mathrm{~h}$ ) for the spirooxindole-pyrrolidine heterocycles. However, the other assay results, such as apoptosis, oxidative stress, and caspase activity, were almost the same for both of the chemical moieties under similar experimental conditions. In addition, the response of the spirooxindole-pyrrolidine heterocycles towards noncancer cells is the same as the $N$-pyridinylmethyl-engrafted bisarylmethylidenepyridinones, revealing that the chemical moiety is able to differentiate between the aggressively growing cancer and nonaggressive healthy normal cells. This shows that the spirooxindole-pyrrolidine heterocycles can be employed for the prolonged therapeutic actions against cancer cells; for a similar but quicker effect, the $N$-pyridinylmethyl-engrafted bisarylmethylidenepyridinones are more suitable.

\section{Conclusions}

The biological evaluation of our synthesized compounds $\mathbf{1}(\mathbf{a}-\mathbf{h})$ revealed that all the derivatives exhibit anticancer activity against HepG2 cancer cells, and this activity is quite high at the $48 \mathrm{~h}$ incubation period. Additionally, the mechanistic investigation of the highly active compound $\mathbf{1} \mathbf{b}$ provided the information that the cells are experiencing an apoptotic pathway, with the induction of oxidative stress carried by ROS and the involvement of caspases. The observed activity of compound $\mathbf{1 b}$ at a very low $\mathrm{IC}_{50}$ value and, at the same time, its not-very-aggressive nature against noncancer cells indicate the potential role that can be played by spiropyrrolidine derivatives as chemotherapeutic agents.

Supplementary Materials: The following are available online at http://www.mdpi.com/2227-9717/8/11/1473/s1.

Author Contributions: R.S.K.: conceptualization, writing original draft preparation, and supervision; D.M.A.-t.: investigation; A.I.A.: investigation, supervision, and funding acquisition; N.A.: investigation; F.M.: investigation, writing, and original draft preparation. All authors have read and agreed to the published version of the manuscript.

Funding: This research was funded by the Deanship of Scientific Research, King Saud University, Riyadh, Saudi Arabia, through the grant number RG-1438-052.

Acknowledgments: The authors thank Stellixir Biotech Pvt. Ltd, Bangalore, India for performing the biological assays. The authors also thank the Deanship of Scientific Research, King Saud University, Riyadh, Saudi Arabia for funding this work through the grant number RG-1438-052.

Conflicts of Interest: The authors declare no conflict of interest.

\section{References}

1. Bray, F.; Ferlay, J.; Soerjomataram, I.; Siegel, R.; Torre, L.A.; Jemal, A. Global cancer statistics 2018: GLOBOCAN estimates of incidence and mortality worldwide for 36 cancers in 185 countries. CA Cancer J. Clin. 2018, 68, 394-424. [CrossRef]

2. Ames, B.N.; Gold, L.S.; Willett, W.C. The causes and prevention of cancer. Proc. Natl. Acad. Sci. USA 1995, 92, 5258-5265. [CrossRef]

3. Seyfried, T.N.; Huysentruyt, L.C. On the origin of cancer metastasis. Crit. Rev. Oncog. 2013, 18, 43-73. [CrossRef] [PubMed]

4. Blackadar, C.B. Historical review of the causes of cancer. World J. Clin. Oncol. 2016, 7, 54-86. [CrossRef] [PubMed] 
5. Schirrmacher, V. From chemotherapy to biological therapy: A review of novel concepts to reduce the side effects of systemic cancer treatment (Review). J. Oncol. 2019, 54, 407-419.

6. Mansoori, B.; Mohammadi, A.; Davudian, S.; Shirjang, S.; Baradaran, B. The different mechanisms of cancer drug resistance: A brief review. Adv. Pharm. Bull. 2017, 7, 339-348. [CrossRef]

7. Roy, S.; Kumar, A.; Islam, M.S.; Rabbi, F.A.; Paul, P.; Mia, M.M.; Islam, A.K.M.K.; Ray, A.K. Drug resistance and its future perspectives in cancer treatment. Asian Oncol. Res. J. 2020, 3, 26-46.

8. Cotter, T.G. Apoptosis and cancer: The genesis of a research field. Nat. Rev. Cancer. 2009, 9, 501-507. [CrossRef]

9. Plati, J.; Bucur, O.; Khosravi-Far, R. Dysregulation of apoptotic signaling in cancer: Molecular mechanisms and therapeutic opportunities. J. Cell. Biochem. 2008, 104, 1124-1149. [CrossRef]

10. Chande, M.S.; Verma, R.S.; Barve, P.A.; Khanwelkar, R.R.; Vaidya, R.B.; Ajaikumar, K.B. Facile synthesis of active antitubercular, cytotoxic and antibacterial agents: A Michael addition approach. Eur. J. Med. Chem. 2005, 40, 1143-1148. [CrossRef]

11. Lundahl, K.; Schut, J.; Schlatmann, J.L.; Paerels, G.B.; Peters, A. Synthesis and antiviral activities of adamantane spiro compounds. 1. Adamantane and analogous spiro-3'-pyrrolidines. J. Med. Chem. 1972, 15, 129-132. [CrossRef] [PubMed]

12. Yang, J.; Liu, X.; Wang, D.; Tian, M.; Han, S.; Feng, T.; Liu, X.; Mei, R.; Zhou, Y. Diversity-oriented one-pot multicomponent synthesis of spirooxindole derivatives and their biological evaluation for anticancer activities. Tetrahedron 2016, 72, 8523-8536. [CrossRef]

13. Lotfy, G.; Said, M.M.; Ashry, E.E.; Tamany, E.S.; Al-Dhfyan, A.; Aziz, Y.M.; Barakat, A. Synthesis of new spirooxindole-pyrrolothiazole derivatives: Anti-cancer activity and molecular docking. Bioorg. Med. Chem. 2017, 254, 1514-1523. [CrossRef] [PubMed]

14. Barakat, A.; Islam, M.S.; Ghawas, H.M.; Al-Majid, A.; El-Senduny, F.F.; Badria, F.; Elshaier, Y.A.; Ghabbour, H. Substituted spirooxindole derivatives as potent anticancer agents through inhibition of phosphodiesterase 1. RSC Adv. 2018, 8, 14335-14346. [CrossRef]

15. Kornet, M.J.; Thio, A.P. Oxindole-3-spiropyrrolidines and -piperidines. Synthesis and local anesthetic activity. J. Med. Chem. 1976, 19, 892-898. [CrossRef] [PubMed]

16. Maclean, D.; Schullek, J.R.; Murphy, M.M.; Ni, Z.J.; Gordon, E.M.; Gallop, M.A. Encoded combinatorial chemistry: Synthesis and screening of a library of highly functionalized pyrrolidines. Proc. Natl. Acad. Sci. USA 1997, 94, 2805-2810. [CrossRef]

17. Lo, M.M.-C.; Neumann, C.S.; Nagayama, S.; Perlstein, E.O.; Schreiber, S.L. A Library of Spirooxindoles Based on a Stereoselective Three-Component Coupling Reaction. J. Am. Chem. Soc. 2004, 126, 16077-16086. [CrossRef]

18. Jossang, A.; Jossang, P.; Hadi, H.A.; Sevenet, T.; Bodo, B. Horsfiline, an oxindole alkaloid from Horsfieldia superba. J. Org. Chem. 1991, 56, 6527-6530. [CrossRef]

19. Pellegrini, C.; Weber, M.; Borschberg, H.-J. Total Synthesis of (+)-Elacomine and (-)-Isoelacomine, Two Hitherto Unnamed Oxindole Alkaloids from Elaeagnus commutate. Helvitica 1996, 79, 151-168.

20. Galliford, C.V.; Scheidt, K.A. Pyrrolidinyl-spirooxindole natural products as inspirations for the development of potential therapeutic agents. Angew. Chem. Int. Ed. 2007, 46, 8748-8758. [CrossRef]

21. Roeder, E.; Wiedenfeld, H. Pyrrolizidine alkaloids in plants used in the traditional medicine of Madagascar and the Mascarene islands. Pharmazie 2011, 66, 637-647. [PubMed]

22. Wang, S.; Zhao, Y.; Aguilar, A.; Bernard, D.; Yang, C.-Y. Targeting the MDM2-p53 Protein-Protein Interaction for New Cancer Therapy: Progress and Challenges. Cold Spring Harb. Perspect. Med. 2017, 7, a026245. [CrossRef] [PubMed]

23. Almansour, A.I.; Kumar, R.S.; Beevi, F.; Shirazi, A.N.; Osman, H.; Ismail, R.; Choon, T.S.; Sullivan, B.; McCaffrey, K.; Nahhas, A.; et al. Facile, Regio- and Diastereoselective Synthesis of Spiro-Pyrrolidine and Pyrrolizine Derivatives and Evaluation of Their Antiproliferative Activities. Molecules 2014, 19, 10033-10055. [CrossRef]

24. Almansour, A.I.; Arumugam, N.; Kumar, R.S.; Subbarayan, P.V.; Alshatwi, A.A.; Ghabbour, H.A. Anticancer Agents. U.S. Patent 9,486,444 B1, 8 November 2016.

25. Almansour, A.I.; Arumugam, N.; Kumar, R.S.; Subbarayan, P.V.; Alshatwi, A.A.; Athinarayanan, J. Anticancer Agents. U.S. Patent 9,873,699B1, 23 January 2018. 
26. Kia, Y.; Osman, H.; Kumar, R.S.; Basiri, A.; Murugaiyah, V. Synthesis and discovery of highly functionalized mono- and bis-spiro-pyrrolidines as potent cholinesterase enzyme inhibitors. Bioorg. Med. Chem. Lett. 2014, 24, 1815-1819. [CrossRef] [PubMed]

27. Filosa, R.; Peduto, A.; de Caprariis, P.; Saturnino, C.; Festa, M.; Petrella, A.; Pau, A.; Pinna, G.A.; Colla, P.L.; Busonera, B.; et al. Synthesis and antiproliferative properties ofN3/8-disubstituted3,8-diazabicyclo [3.2.1]octane analogues of 3,8-bis[2-(3,4,5-trimethoxyphenyl)pyridin-4-yl]methyl-piperazine. Eur. J. Med. Chem. 2007, 42, 293-306. [CrossRef] [PubMed]

28. Carreira, E.M.; Fessard, T.C. Four-membered ring-containing spirocycles: Synthetic strategies and opportunities. Chem. Rev. 2014, 114, 8257-8322. [CrossRef]

29. Zheng, Y.-J.; Tice, C.M. The utilization of spirocyclic scaffolds in novel drug discovery. Expert Opin. Drug Discov. 2016, 11, 831-834. [CrossRef]

30. Al-thamili, D.M.; Almansour, A.I.; Arumugam, N.; Mohammad, F.; Kumar, R.S. Functionalized N-pyridinylmethyl engrafted bisarylmethylidenepyridinones as anticancer agents. Processes 2020, 8, 1154. [CrossRef]

31. Kumar, R.S.; Al-thamili, D.M.; Almansour, A.I.; Arumugam, N.; Dege, N. [Bmim]Br accelerated one-pot three-component cascade protocol for the construction of spirooxindole-pyrrolidine heterocyclic hybrids. Molecules 2020, 25, 4779. [CrossRef]

Publisher's Note: MDPI stays neutral with regard to jurisdictional claims in published maps and institutional affiliations. 